\title{
Assessing the increase of solar fields in Iberian Peninsula
}

\author{
Paula Bastida-Molina ${ }^{1}$, David Alfonso-Solar ${ }^{2}$, Carlos Vargas-Salgado ${ }^{1}$, Lina \\ Montuori $^{2}$ \\ ${ }^{1}$ Department of Electrical Engineering, Universitat Politecnica de Valencia, Spain, \\ ${ }^{2}$ Department of Applied Thermodynamics, Universitat Politecnica de Valencia, Spain.
}

\begin{abstract}
Spanish electrical generation has traditionally included high pollutant energy resources, like fuel or carbon. However, disturbing ever-increase in the average temperature of Planet Earth has led to a search for sustainability in the energy scenario. Therefore, Spanish electrical generation mix is prone to replace contaminant energy resources by non-contaminant, such renewables. Concretely, Spain is one of the countries with more solar peak annual hours. Nevertheless, having enough space to increase solar fields has been widely question. In this paper, an unrealistic scenario where all the annual Spanish consumption would be covered by photovoltaics is deeply analysed. Considering real electrical Spanish consumption data from 2017, required total quantity of solar panels has been quantified. Additionally, the study takes the hypothesis that all the panels should be placed on Spanish sunny desert zones for two main reasons. First, total solar peak annual hours there are higher than in other Spanish regions. Last, making there the installation would give use to previous wasted zones. Obtained results indicate that around 691 million of $330 W_{p}$ solar panels would be required for this issue, taking up $3799 \mathrm{~km}^{2}$. This space means only a $0.77 \%$ of all Iberian Peninsula. These outcomes clearly show that there is suitable and enough space to increase solar fields in Iberian Peninsula.
\end{abstract}

Keywords: Photovoltaics, solar fields, space, increase, Iberian Peninsula. 


\section{Introduction}

Our Planet has been suffering a worrisome temperature growth for years, caused mainly by the enormous amount of carbon dioxide emitted to the atmosphere. If average temperature of Planet Earth continues increasing, the consequences for coming generations will be devastating (Ziegler, Morelli, \& Fawibe, 2019). Preventing this situation has become one of the most important problems for almost every country. Therefore, a wide range of preventing climate change policies are being develop all over the world.

Regarding Spain, electrical generation has traditionally used high polluting sources, like fuel or carbon, or low polluting sources like natural gas. In 2016, electricity generation mix was formed by a $7 \%$ of fuel sources, $18 \%$ of carbon sources and $17 \%$ of natural gas sources. Non-polluting electricity generation sources (nuclear and renewables) represented $57 \%$ of all the generation mix. However, renewables had only a weight of $25 \%$ of the total mix ("International Energy Agency," 2018). The necessity of reducing $\mathrm{CO}_{2}$ emissions together with the recent Spanish policy measures to promote renewable energies have boosted the introduction of higher levels of renewable sources for electricity generation, with the corresponding reduction of high polluting sources ("Red Eléctrica de España Series estadísticas nacionales," 2017).

Furthermore, Spain is one of the countries with more solar peak annual hours, so that photovoltaic solar energy could be the most suitable renewable energy to produce large quantities of clean energy (Saiz Jiménez, Hurtado Pérez, \& Saiz Melia, 2017). The Spanish regions with the highest number of solar peak annual hours are placed in the south-east of Iberian Peninsula, where vast and wasted desert zones are placed. Hence, using these areas to create big solar photovoltaic fields seems a great solution to generate clean energy.

The aim of this research is to finally calculate if Spain has enough and suitable space to increase solar fields. To this issue, an unrealistic scenario where all the 2017 annual electrical Spanish consumption is covered by solar photovoltaic energy has been studied. Canary Islands and Baleares Islands are not consider in this work, so that only Iberian Peninsula is taken into account.

\section{Design process}

\subsection{Solar peak annual hours}

The total quantity of solar photovoltaic energy necessary to cover all the Iberian Peninsula electrical consumption should be calculated considering that the solar fields will be placed in the Spanish regions with highest solar peak annual hours. These communities are the ones located in the south-east of Iberian Peninsula, like Murcia, Almería, Jaén, Granada o 
Albacete. It won't be optimal to install them in the Vasc Country or Navarra, for instance (AEMET, 2019).

Moreover, it is necessary to design the installation for the most unfavorable month, being it the one with the highest relation between electrical demand and solar photovoltaic generation. Since the installation will be placed in Iberian Peninsula, this month will be a winter month because it is in this season when solar radiation is lower. For this situation, most suitable annual tilt of solar panels is $60^{\circ}$, so that winter solar gain is facilitated (Bastida Molina, 2016).

Hence, using free software tool PVGIS, it is possible to obtain monthly solar radiation for a $60^{\circ}$ tilt for every south-east region of Iberian Peninsula measured in solar peak hours $(\mathrm{SPH})$. With these data, average monthly south-east Spanish regions radiation is calculated.

Table 1. Iberian Peninsula monthly SPH.

\begin{tabular}{lcccccc}
\hline Month & Murcia & Almería & Jaén & Granada & Albacete & Average \\
\hline January & 154,38 & 158,41 & 138,88 & 149,11 & 128,34 & 145,82 \\
February & 151,20 & 162,12 & 151,20 & 153,72 & 140,28 & 151,70 \\
March & 184,76 & 196,54 & 180,42 & 184,45 & 171,74 & 183,58 \\
April & 161,10 & 173,10 & 155,70 & 156,60 & 155,40 & 160,38 \\
May & 161,51 & 165,23 & 159,65 & 158,10 & 155,62 & 160,02 \\
June & 157,20 & 156,60 & 159,60 & 158,70 & 155,70 & 157,56 \\
July & 170,50 & 167,71 & 176,08 & 174,22 & 175,15 & 172,73 \\
August & 179,80 & 182,59 & 189,41 & 187,55 & 181,97 & 184,26 \\
September & 169,80 & 179,70 & 177,90 & 178,80 & 170,40 & 175,32 \\
October & 173,60 & 183,21 & 178,56 & 185,07 & 165,85 & 177,26 \\
November & 149,10 & 157,80 & 144,00 & 152,10 & 132,90 & 147,18 \\
December & 140,43 & 154,69 & 136,40 & 149,42 & 124,00 & 140,99 \\
\hline
\end{tabular}

Source: PVGIS (2019).

\subsection{Electrical demand}

The present work is referred to 2017. Monthly real electrical demand of Iberian Peninsula of this year is obtained from ("Red Eléctrica de España | Series estadísticas nacionales," 2017). 
Table 2. Monthly electrical demand of Iberian Peninsula (GWh)

\begin{tabular}{lc}
\hline Month & Electrical demand \\
\hline January & 23.078 \\
February & 19.959 \\
March & 21.087 \\
April & 18.963 \\
May & 20.205 \\
June & 21.680 \\
July & 22.413 \\
August & 21.769 \\
September & 20.145 \\
October & 20.161 \\
November & 20.893 \\
December & 22.151 \\
\hline Source: Red Eléctrica Española (2017)
\end{tabular}

\subsection{Most unfavorable month choice}

Once average monthly SPH (Table 1) and Electrical Demand in 2017 (Table 2) of Iberian Peninsula are determine, it is possible to stablish what is the most unfavorable month in terms of energy. This month will be the one with highest relation between electrical demand and solar photovoltaic generation (Bastida Molina, 2016). Average monthly radiation is expressed in $\mathrm{SPH}$, which is equivalent to $\mathrm{kWh} / \mathrm{m}^{2}$. For having a coherent relation between this parameter and monthly electrical demand, this last term should be expressed in $\mathrm{kWh}$, as Table 3 indicates.

Table 3. Most unfavorable month choice.

\begin{tabular}{lccc}
\hline Month & SPH & $\begin{array}{c}\text { Electrical demand } \\
(\mathbf{k W h})\end{array}$ & Relation \\
\hline January & 145,82 & 23.078 .000 .000 & $158.259 .271,45$ \\
\hline \multicolumn{3}{l}{ Source: PVGIS (2018), Red Eléctrica Española (2017) and own elaboration. }
\end{tabular}

Finally, most unfavorable month is January, as Table 3 shows, so that the installation will be design for this month. On the one, it is verify that this month takes places in winter, as previous hypothesis has stablished. On the other hand, the solar photovoltaic installation 
needs to be design for this month, since it is the one with highest and most unsuitable energy conditions.

\section{Number of solar photovoltaic panels}

Considering the month of designing (the most unfavorable in terms of energy), the electrical demand and the SPH of this month, the total number of solar panels to install could be calculated and therefore the total solar photovoltaic power. Designing parameters are summarized in Table 3.

The total initial power of the installation $\left(\mathrm{P}_{\mathrm{i}}\right)$ can be expressed by equation (1), where $\mathrm{E}_{\mathrm{d}}$ represents monthly electrical demand of January and SPH indicates the quantity of solar peak hours of the same month.

$P_{i}=\frac{E_{d}}{S P H}$

This factor needs to be increased by two more terms (Bastida Molina, Saiz Jiménez, Molina Palomares, \& Álvarez Valenzuela, 2017), like equation (2) shows. Hence, final total power of the installation $\left(\mathrm{P}_{\mathrm{f}}\right)$ can be determine.

On the one hand, term $\mathrm{k}_{1}$ encompasses all the global losses that could occur in the installation and that are all different in nature. Some of these losses could be the reduction of the installation efficiency due to the accumulated dirt on the panels, drops in voltage in wires, differences among fabrication tolerances of the equips, differences among the operation of the panels...(Lu \& Zhao, 2019). A wide span of studies claim that obtaining the exact value of this term turns out to be certainly complicated, since it does not follow a mathematical method and the variability of all the losses that it includes is very diverse (Bastida Molina, 2016; Bastida Molina, Saiz Jiménez, et al., 2017; Bastida Molina, Saiz Jiménez, \& Molina Palomares, 2017). These works have quantified this term in 1.2, meaning that initial power of the solar field is increased in a $20 \%$.

On the other hand, term $\mathrm{k}_{2}$ includes the losses of solar panels due to the test of time. This information should be given by the manufacturer. As standard procedure, panels suffer a lineal decrease of their efficiency due to the test of time of $20 \%$ during the firsts 25 years, so that $\mathrm{k}_{2}$ has a value of 1.2. ("Garantía lineal potencia Módulos Fotovoltaicos Estándar ATERSA," 2013).

$P_{f}=P_{i} \cdot k_{1} \cdot k_{2}$

Once total final power of the installation is obtain, it is possible to calculate the quantity of panels $\left(\mathrm{N}_{\mathrm{p}}\right)$ of the solar field in question. To this issue, it is considered that an individual panel has a nominal power of $330 \mathrm{~W}_{\mathrm{p}}$ (Saiz Jiménez et al., 2017). Equation (3) is used to 
this aim, where total final power of the installation $\left(\mathrm{P}_{\mathrm{f}}\right)$ and the nominal power of an individual panel $\left(\mathrm{P}_{\mathrm{p}}\right)$ are considered.

$N_{p}=\frac{P_{f}}{P_{p}}$

Applying this methodology, it has been possible to know that the solar field in question would ideally be formed by 691 million of panels with $228 \mathrm{GW}$ of total power, like Table 4 indicates.

Table 4. Number of panels and total power of the solar field in question.

\begin{tabular}{cc}
\hline Number of pannels (million) & Total power $(\mathbf{G W})$ \\
\hline 691 & 228 \\
\hline \multicolumn{2}{c}{ Source: Own elaboration. }
\end{tabular}

\section{Area of the total installation}

The total area of the studied solar photovoltaic installation depends on the horizontal area of the solar panel $\left(A_{h}\right)$ and the distance to dispose among rows of panels to prevent them from shading $(d)$.

Standard dimensions of $330 \mathrm{Wp}$ solar photovoltaic panels are about 1960.40.990. mm (height · width · length). Moreover, its tilt is also defined $\left(60^{\circ}\right)$, as the most unfavorable month in terms of energy is January. Hence, considering both factors, horizontal area of solar photovoltaic panels could be obtained with equation (4), where 1 indicates length dimension, h high dimension and t represents the tilt.

$A_{h}=l \cdot h \cdot \cos (t)$

This area should also be increased by the area that needs to be provided among rows of panels to prevent them from shadowing (Oh \& Park, 2018). The methodology followed to determine the appropriate distance lies in multiplying relative height of the panels by a factor. This factor depends on the latitude of location of the installation, that acquires a value of $40^{\circ}$ for Iberian Penninsula. Equation (5) is used to calculate the distance among rows of panels, where $\mathrm{d}$ indicates distance, lat latitude and $\mathrm{h}$ height.

$d=\frac{1}{\operatorname{tg}(61-l a t)} \cdot h$

Therefore, the required area among rows of panels to prevent shading $\left(\mathrm{A}_{\mathrm{s}}\right)$ could be obtain by equation (6), where distance (d) and length of the panel are considered (l). 
$A_{s}=l \cdot d$

Finally, considering these two areas, the total area that takes up one individual panel $\left(A_{p}\right)$ could be obtain by equation (7). Knowing this value and the total number of solar photovoltaic panels that formed the installation, the total area $\left(\mathrm{A}_{\mathrm{t}}\right)$ that the solar field needs is finally determine by equation (8).

$A_{p}=A_{h}+A_{s}$

$A_{t}=A_{p} \cdot N_{p}$

Hence, it has been possible to determine the total area that the solar photovoltaic field required to cover all the electrical demand of Iberian Peninsula would take up: $3799 \mathrm{~km}^{2}$.

Table 5. Total area of the solar photovoltaic field in question $\left(\mathrm{km}^{2}\right)$.

\begin{tabular}{c}
\hline Total area \\
\hline 3799 \\
\hline Source: Own elaboration
\end{tabular}

\section{Conclusions}

The uncontrolled quantity of $\mathrm{CO}_{2}$ emissions that have been emitted to the atmosphere for years have led to a disturbing temperature raise of Planet Earth. A wide span of climate change policies are being developed in almost every country, so that most polluting activities tend to disappear.

Regarding Spain, its electrical generation mix is suffering a transformation, since renewable energies are being introduced. Therefore, with this paper it has been possible to verify that the high number of annual SPH of Spanish Iberian Peninsula (1957) make solar photovoltaic energy an ideal clean energy to generate electricity in this country. Moreover, the unrealistic scenario of covering all the electrical consumption that was really demanded in 2017 with solar photovoltaic energy has been analyzed. Results have proved that the required solar field would take up an area of $3799 \mathrm{~km}^{2}$, which only represents a $0.77 \%$ of all Iberian Peninsula. South-east regions of Iberian Peninsula are the most suitable ones to place the installation for different reasons. First, these communities are the ones with highest SPH of the Peninsula. Last, large desert zones with no use are located in south-east regions, so installing the solar field there would give use to a previous wasted zone.

To sum up, Iberian Peninsula is likely to increase the percentage of solar photovoltaic energy in the electricity generation mix since it has suitable and enough space to achieve it. 


\section{Acknowledgment}

This work was supported in part by the regional public administration of Valencia under the grant ACIF/2018/106.

\section{References}

AEMET. (2019). Atlas de radiación solar en España. Retrieved from http://www.aemet.es/es/serviciosclimaticos/datosclimatologicos/atlas_radiacion_solar

Bastida Molina, P. (2016). Estudio de distintas alternativas fotovoltaicas para alimentación de una instalación. Retrieved from https://riunet.upv.es/handle/10251/74582

Bastida Molina, P., Saiz Jiménez, J. Á., Molina Palomares, M. P., \& Álvarez Valenzuela, B. (2017). Instalaciones solares fotovoltaicas de autoconsumo para pequeñas instalaciones. Aplicación a una nave industrial. 3C Tecnología, 1-14. https://doi.org/http://dx.doi.org/10.17993/3ctecno.2017.v6n1e21.1-14

Bastida Molina, P., Saiz Jiménez, J. A., \& Molina Palomares, P. (2017). Pequeñas instalaciones alimentadas por sistemas solares de autoconsumo Aplicación a un caso real.

Garantía lineal potencia Módulos Fotovoltaicos Estándar ATERSA. (2013). Retrieved December 26, 2018, from http://www.atersa.com/Common/pdf/atersa/garantias/Garantias-Modulos-Nov13.pdf

International Energy Agency. (2018). Retrieved June 28, 2019, from https://www.iea.org/statistics/electricity/

Lu, H., \& Zhao, W. (2019). CFD prediction of dust pollution and impact on an isolated ground-mounted solar photovoltaic system. Renewable Energy, 131, 829-840. https://doi.org/10.1016/J.RENENE.2018.07.112

Oh, M., \& Park, H.-D. (2018). A new algorithm using a pyramid dataset for calculating shadowing in solar potential mapping. Renewable Energy, 126, 465-474. https://doi.org/10.1016/J.RENENE.2018.03.068

Red Eléctrica de España | Series estadísticas nacionales. (2017). Retrieved December 26, 2018, from Red Eléctrica Española website: https://www.ree.es/es/estadisticas-delsistema-electrico-espanol/series-estadisticas/series-estadisticas-nacionales

Saiz Jiménez, J. Á.; Hurtado Pérez, E., \& Saiz Melia, Á. (2017). "Energía solar fotovoltaica y consumo eléctrico en España." Retrieved December 26, 2018, from Valencia Plaza website: https://valenciaplaza.com/energia-solar-fotovoltaica-yconsumo-electrico-en-espana

Ziegler, C., Morelli, V., \& Fawibe, O. (2019). Climate Change and Underserved Communities. Physician Assistant Clinics, 4(1), 203-216. https://doi.org/10.1016/j.cpha.2018.08.008 